\title{
ANALISIS KUALITAS MANAJEMEN BANDARA HALIM PERDANAKUSUMA DAN PENGARUHNYA TERHADAP KEPUASAN PELANGGAN TRANSPORTASI UDARA
}

\author{
Bambang B Sulistiyono ${ }^{1}$, Sherly Olivia²
}

\begin{abstract}
Since commercialization Halim Airport, very interesting passengers who use air transport services because of its position in the city center.

The Number of passengers continues to increase from year to year. So the airport management is required to furnish the service that needs of passengers. An advanced security aspects task AVSEC. This study aims to examine the effect of AVSEC (Air Transport Service) personnel capabilities and sensitivity to customer satisfaction in Halim Perdanakusuma Airport, empirically, either partially or simultaneously.

This research is a quantitative descriptive study. The total population are 132 people, divided into two population, namely 66 of AVSEC officers and 66 passengers. The sample surveyed by sex, education and age. Data were analyzed by using descriptive statistics such as the Average of scores and cross tabulations Test results show that the AVSEC officer had run of function and duty well but the level of user satisfaction aviation transport services have not run yet.
\end{abstract}

\section{Keywords: Ability, Sensitivity and Customer Satisfaction Air Transport}

\section{PENDAHULUAN}

$\begin{array}{rrr}\text { Seiring } & \text { dengan } & \text { semakin } \\ \text { meningkatnya } & \text { kemajuan } & \text { teknologi }\end{array}$
kedirgantaraan, menyebabkan Bandar Udara (Bandara) bukan lagi hanya dipandang sebagai tempat untuk mobilitas orang melalui perjalanan udara saja, tetapi sudah mengarah pada tujuan mempromosikan kepentingan daerah melalui keberadaan Bandara itu sendiri. Bila semula fungsi Bandara hanya bersifat kovensional, namun dalam perkembangannya sudah berubah menjadi kawasan penting untuk mendorong pertumbuhan perekonomian dan

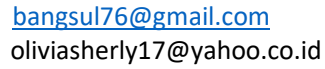

pembangunan suatu wilayah. Hal ini menunjukkan bahwa telah terjadi perubahan signifikan dari peran suatu Bandara.

Jika dalam paradigma lama dikatakan bahwa kemajuan suatu negara hanya bisa terjadi bila negara tersebut mempunyai akses ke laut, sebagaimana yang pernah dilakukan ketika Uni Soviet yang berusaha merebut wilayah Siberia untuk bisa membuka pelabuhan Vladivostok di Samudera Pasifik walaupun letaknya sangat jauh dari di pusat pemerintahan. Akan tetapi sejalan dengan kemajuan tehnologi kedirgantaraan saat ini, tidak ada lagi kata yang mengatakan bahwa suatu 
negara harus memiliki pelabuhan laut jika ingin maju. Dalam arti bahwa kemajuan suatu wilayah saat ini tidak lagi tergantung pada letak geografi wilayahnya yang berpantai, tetapi sebaliknya suatu negara atau wilayah akan mengalami kemajuan perekonomian bila di wilayahnya terdapat Bandara. Sebagai ilustrasi bahwa kota-kota besar seperti Medan, Makasar, Bandung, Malang, Yogyakarta terus berupaya mengembangkan Bandara sampai pada tingkat internasional. Demikian gambaran yang lain, daerah pedalaman Kabupaten Wamena yang letaknya ditengah tengah pegunungan Jaya Wijaya Papua, mampu bergerak perekonomiannya hanya karena memiliki Bandara.

Perubahan paradigma tersebut semakin menyadarkan orang akan pentingnya peran Bandara, sehingga pembenahan manajemen Bandara secara modern sudah harus diterapkan dengan kepuasan pelanggan merupakan target utama dalam pelayanan yang harus dilakukan. Menghadapi tuntutan pasar yang demikian tidak ada pilihan lain bagi perusahaan jasa penerbangan untuk berupaya memberikan berbagai jasa layanan berkualitas agar pelanggan tetap setia menggunakan moda transportasi dirgantara, sebagaimana dikatakan oleh Kotler dalam Suprayanto dan Rosad (2015:134) bahwa kepuasan pelanggan dinilai dari kualitas jasa yang didapatkan pelanggan.
Semakin padatnya jadwal penerbangan di Bandara Soekarno-Hatta yang menyebabkan banyak keluhan pengguna jasa penerbangan nasional maupun internasional seperti dellay penerbangan yang melebihi toleransi waktu sampai keterlambatan jadwal ketibaan pesawat karena harus antri pendaratan, menyebabkan Kementerian Perhubungan melalui Perum Angkasa Pura (PAP) II, berupaya menghidupkan kembali Bandara Halim Perdanakusuma menjadi Bandara komersial sejak 10 Februari 2014, yang sebelumnya hanya digunakan sebagai Bandara yang melayani penerbangan VVIP dan Charter filght. Selain letak posisinya yang strategis di tengah kota, perjalanan yang dilakukan oleh calon penumpang lebih efektif dan efisien dibandingkan jika menggunakan penerbangan di Bandara Soetta. Peluang inilah kemudian ditangkap oleh operator penerbangan Lion Grup dan Garuda Grup untuk menambah route penerbangan baru tanpa kajian lingkungan yang mendalam sehingga munculnya berbagai persoalan seperti; terjadinya penundaan penerbangan (dellay) sampai dengan pembatalan (cancel) karena selain padat penerbangan, juga digunakannya untuk pelayanan penerbangan VVIP Presiden/Wakil Presiden atau pejabat tinggi/ negara asing yang harus didahulukan.

Kondisi Bandara Halim PK yang memang tidak dipersiapkan untuk menjadi Bandara Komersil, menambah persoalan 
baru bagi penumpang karena terbatasnya ruang tunggu penumpang, kamar mandi dan ruang ibadah, demikian pula sempitnya ruang gerak penumpang. Selain dari pada itu dengan statusnya sebagai Bandara Internasional maka sensitivitas Bandara juga semakin meningkat seperti menjadi sasaran terorisme, pembajakan maupun peredaran narkoba. Di luar hal tersebut masih terdapat persoalan ikutan lainnya yang tidak kalah pentingnya seperti macetnya jalan keluar di depan pintu gerbang Bandara pada saat jamjam sibuk antara pukul 14.00 s.d 19.00, meningkatnya angka kecelakaan lalu lintas, polusi udara dari pesawat maupun kendaraan bermotor, tumbuhnya usaha kaki lima yang semakin mengurangi kenyamanan lingkungan, munculnya transportasi liar seperti ojek, grab yang parkir sembarangan dan lain sebagainya. Menghadapi kondisi tersebut menyebabkan banyak penumpang yang merasa kecewa, bahkan marah terhadap layanan yang diberikan oleh pihak Bandara selama ini. Yang tidak kalah pentingnya, masyarakat sekitar lingkungan di luar Bandara yang mengalami frustasi karena kemacetan dan dampak lingkungan lainnya, seperti kebisingan, polusi dan sebagainya.

Berikut disajikan data peningkatan frequensi penerbangan dan peningkatan jumlah penumpang yang menggunakan Bandara Halim pada 2015. sebagai berikut :

\section{GRAFIK}

Data Jumlah Pesawat dan Penumpang 2015
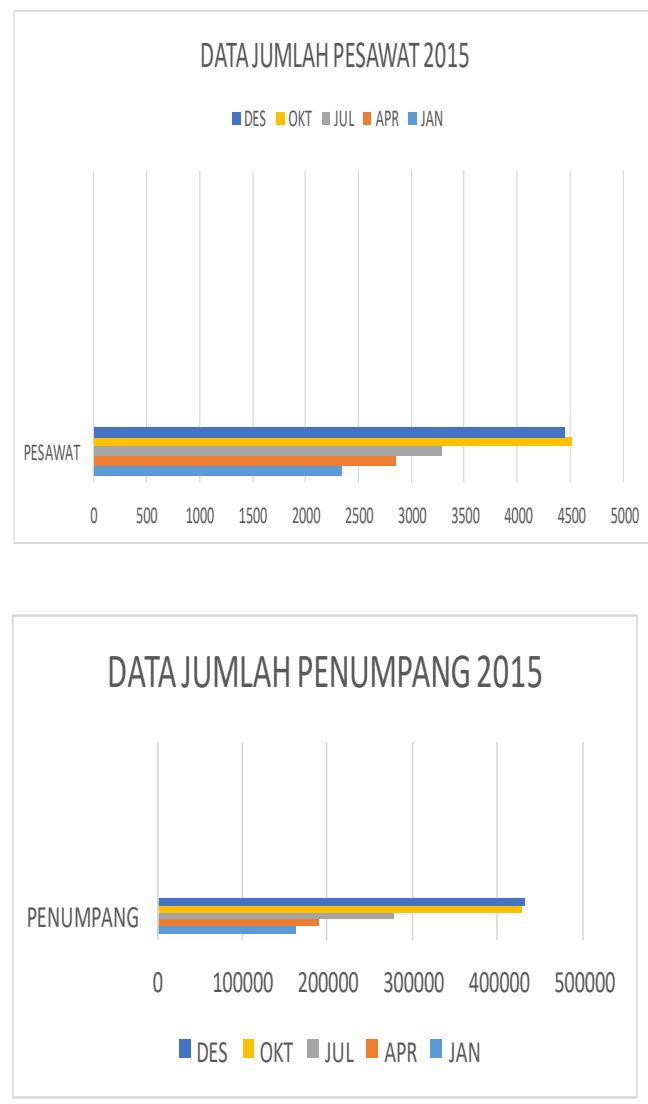

Sumber : data diambil dari Disops Bandara Halim PK pada April 2016

Perlu dipahami bahwa manajemen Bandara mempunyai tugas pokok dan tanggungjawab dalam memberikan layanan yang terbaik bagi penumpang dan lingkungannya yang dalam hal ini dipercayakan kepada Aviation Security (AVSEC). Akan tetapi dari hasil studi pendahuluan yang sudah dilakukan, ternyata masih banyak tugas pokok dan tanggung jawab yang belum dilakukan secara baik. Hal ini tercermin dari banyaknya keluhan ketidakpuasan dari penumpang baik yang akan naik maupun yang turun dari pesawat. 
Berdasarkan temuan tersebut diatas maka telah dilakukan pengidentifikasian masalah untuk diteliti yang berkaitan dengan kepuasan pengguna jasa transportasi udara terhadap jasa layanan yang diberikan oleh petugas keamanan AVSEC di Bandara Halim Perdanakusuma.

\section{TINJAUAN PUSTAKA}

Bandar udara adalah lapangan terbang yang digunakan untuk mendarat dan lepas landas pesawat udara, naik turun penumpang dan atau bongkar muatan kargo atau pos, serta dilengkapi dengan fasilitas keselamatan penerbangan dan sebagai tempat perpindahan antar moda transportasi (Hadi Suharno, 2015:2). Dalam penyelengaraan manajemen bandar udara terdapat tiga komponen utama sub sistem transportasi udara yang saling berinteraksi antara lain: Bandar Udara, Maskapai Penerbangan (Airlines) dan Pengguna Jasa Angkutan Udara (Penumpang). Dimana ketiga sub sistem tersebut di atas harus saling berinteraksi dan seimbang, gambaran Airport System menurut Hadi Suharno,(2015:5,) sebagai berikut :

\section{AIR SUB SYSTEM}

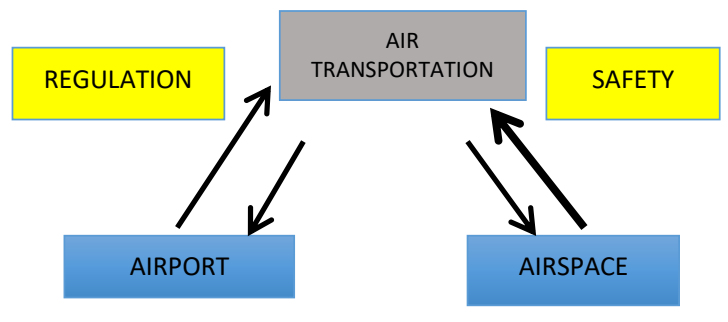

Tarhadap pokok pelayanan kebandarudaraan A. Fathoni (2014:151) menyebutkan terdapat empat sasaran, yaitu; Pertama; terbuka akses seluas-luasnya pada calon pengguna jasa penerbangan dan kelancaran prosedur marketing, Kedua ; tercipta kondisi aman pada setiap penumpang dengan terjaminnya dari setiap kondisi yang menimbulkan rasa keraguan terhadap keselamatan, Ketiga ; faktor keamanan, artinya setiap penumpang dan pengguna jasa penerbangan merasa aman dan terlayani dengan baik, Keempat ; tepat waktu, artinya setiap schedule penerbangan take off dan landing diupayakan untuk tepat waktu, sehingga tidak terjadi penundaan atau keterlambatan jadwal penerbangan, pemberangkatan dan kedatangan.

Karena pengelolaan dunia penerbangan mengandung resiko paling tinggi di antara moda transportasi lainnya maka masalah keamanan penerbangan menjadi prioritas tertinggi yang harus dikelola secara profesinal oleh pihak manajemen. Dalam hal ini pemerintah melalui Kementerian Perhubungan telah mengeluarkan peraturan keamanan bandara yang dalam pelaksanaannya dilakukan oleh petugas khusus pelayanan dan keamanan AVSEC (Aviation Security) dimana setiap personil keamanan penerbangan diwajibkan memiliki kompetensi yang dinyatakan dengan lisensi atau surat tanda kecakapan petugas (SKTP) di bidang keamanan penerbangan. (Peraturan Direktur Jenderal 
Perhubungan Udara Nomor : SKEP/2765/XII/2010 Bab I butir 9).

Demikian pula dalam hal kepekaan yang harus dimiliki oleh setiap petugas yang mempunyai tangung jawab besar terhadap keamanan dan keselamatan penerbangan, Sarlito Wiraman (2014:50-51) menyebutkan bahwa kepekaan sosial merupakan kemampuan untuk menyesuaikan perilaku dengan harapan dan pandangan orang lain. Yang secara sederhana dapat diartikan bahwa kepekaan sosial (social sensitivity) sebagai kemampuan seseorang untuk bereaksi secara cepat dan tepat terhadap objek atau situasi sosial tertentu yang ada di sekitarnya.

Menyangkut masalah kepuasan pelanggan Kuswadi (2006:17) mengatakan; kepuasan pelanggan dipengaruhi oleh : 1) Mutu produk atau jasa, 2) Mutu pelayanan, 3) Pebarawan Harga, 4) Waktu penyerahan dan 5) Keamanan Pelanggan. Selanjutnya Kotler dalam Suprayanto dan Rosad (2015:134-135) menyebutkan ada lima indikator kepuasan antara lain ; 1) Keandalan (reliability), 2) Daya Tanggap (responsiveness), 3) Empati (emphaty), 4) Jaminan (assurance), 5) Berwujud (tangible). Untuk mengukur kepuasan Fandy Tjiptono dan Gregorius Chandra (2006:130) menyebutkan ada empat metode yang dapat digunakan, yaitu : 1) Sistem Keluhan dan Saran Industri, 2) Survei Kepuasan, 3) Ghost Shopping (Pelanggan Bayangan), 4) Analisa Pelanggan.
Dari temuan masalah dan kajian pustaka, dapat divisualisasikan kerangka berpikir sebagai berikut :

\section{Kerangka Berpikir}

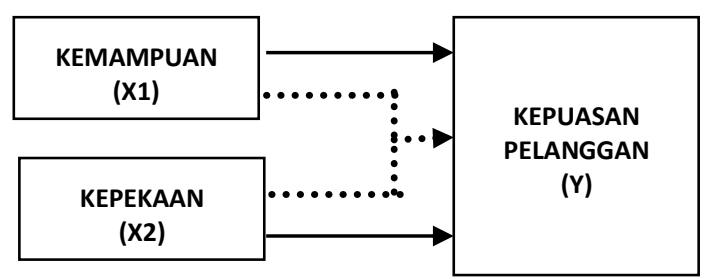

Keterangan : Pengaruh parsial Pengaruh simultan

\section{METODE KEGIATAN}

Penelitian dilakukan di PT. Angkasa Pura II (Persero) Bandara Halim Perdanaksuma yang berlokasi di J1. Halim Perdanakusuma, Jakarta Timur, Daerah Khusus Ibukota Jakarta. Dengan waktu yang dibutuhkan dalam penelitian ini kurang lebih selama 5 bulan dimulai sejak bulan April sampai dengan bulan Agustus 2016,. Adapun subjek maupun objek populasi yang akan diteliti secara generalisasi adalah petugas AVSEC sebanyak 66 orang dan pelanggan (penumpang) transportasi udara bandara Halim Perdanakusuma sebanyak 66 orang penumpang. Karena jumlah terbatas dan mampu di teliti semua maka metode yang digunakan untuk meneliti petugas AVSEC menggunakan metode Sampling Jenuh, sedangkan pelanggan transportasi udara berdasarkan data 2015 jumlahnya cukup banyak lebih dari 4 juta orang maka penentuan sampel menggunakan rumus Isaac 
dan Michael dengan tingkat kesalahan 5\% diperoleh hasil sebanyak 66 orang. Sampel tersebut dianggap sudah dapat mewakili seluruh penunpang yang ada atau hasil analisa yang diperoleh dapat di generalisir. Untuk petugas AVSEC disusun berdasarkan jenis kelamin, usia, jenis pendidikan sedangkan untuk pelanggan hanya jenis kelamin, usia saja jenis pendidikan tidak diambil.

Data yang diteliti adalah data primer yang diperoleh langsung dari sumber asli (tidak melalui media perantara), sehingga peneliti harus melakukan observasi dan pengumpulan data melalui penyebaran kuesioner bagi responden petugas AVSEC maupun penumpang pengguna jasa transportasi Udara di Bandara Halim Perdanakusuma. Dengan tehnik pengumpulan data melalui penyebaran kuesioner langsung pada sumbernya, yang memuat pertanyaan dari ketiga variabel yang akan diteliti. Jenis penelitian yang dipergunakan dalam penelitian ini adalah deskriptif yaitu metode penelitian kuantitatif yang bertujuan membuat kalimat (deskripsi) secara sistematis dan akurat mengenai faktafakta yang terukur dalam angka, selanjutnya di input dan diolah menggunakan program aplikasi komputer SPSS 21.

Analisis dilakukan dengan uji linearitas bertujuan untuk mengetahui apakah dua variabel mempunyai hubungan yang linear atau tidak secara signifikan. Sedangkan Uji normalitas untuk pengujian data empirik atau data penelitian guna mengetahui apakah jenis data yang dikumpulkan di lapangan sesuai dengan distribusi teoritik. Uji Asumsi Klasik juga dilakukan melalui uji multikolonieritas untuk mengetahui adanya hubungan yang kuat antara variable bebas yang digunakan dalam satu model persamaan regresi linear berganda. Dalam penelitian ini juga dilakukan uji heteroskedastisitas untuk mengetahui ada atau tidaknya penyimpangan asumsi klasik heteroskedastisitas .

\section{HASIL PENELITIAN DAN PEMBAHASAN}

Analisa data dilakukan berdasarkan statistik deskriptif dengan menggunakan distribusi frekuensi dan presentase untuk karakteristik responden dan skor rata rata untuk efektifitas infografis, serta tabulasi silang untuk menganalisis efektivitas infografis berdasarkan karakteristik. Hasil analisis data disajikan dalam bentuk diagram pie dan clustered column. Angka yang diperoleh sebagai hasil perhitungan statistik di interpretasikan secara diskriptif dalam pembahasan.

\section{Karakteristik Responden}

Karakteristik responden yang dianalisis meliputi jenis kelamin, usia dan jenis pendidikan yang diakses dan dianalisis menggunakan distribusi frekuensi dan 
presentase yang secara lengkap dapat disajikan dalam diagram pie sebagai berikut $\therefore$

\section{Gambar}

Jumlah Responden

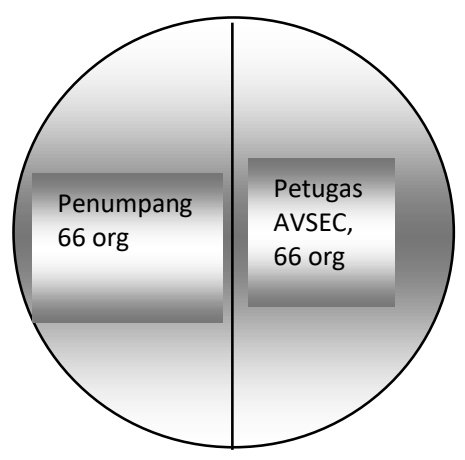

Hal ini untuk menggambarkan jumlah responden yang diteliti atau sebagai obyek penelitian yang seimbang antara petugas AVSEC dengan penumpang pengguna jasa transportasi udara yaitu masing masing 66 orang, yang dapat dijelaskan sebagai berikut : jumlah petugas AVSEC saat ini yang dimiliki oleh Bandara Halim sebanyak 66 orang karena jumlahnya sedikit maka semuannya ditetapkan sebagai responden sehingga yang digunakan adalah metode sampling jenuh. Sedangkan untuk penumpang jasa transportasi berdasarkan data 2015 berjumlah lebih dari 4 juta orang yang diasumsikan sampai Desember 2016 tidak mengalami kenaikan yang signifikan atau dianggap tetap maka penentuan sampel menggunakan dengan tabel sampel yang diketemukan jumlahnya sebanyak 66 orang selanjutnya hasil analisa yang diperoleh nantinya dapat digeneralisir kepada semua pelanggan (penumpang) jasa transportasi udara yang menggunakan Bandara Halim Perdanakusuma.

\section{Gambar}

Jenis Kelamin Penumpang dan Petugas AVSEC
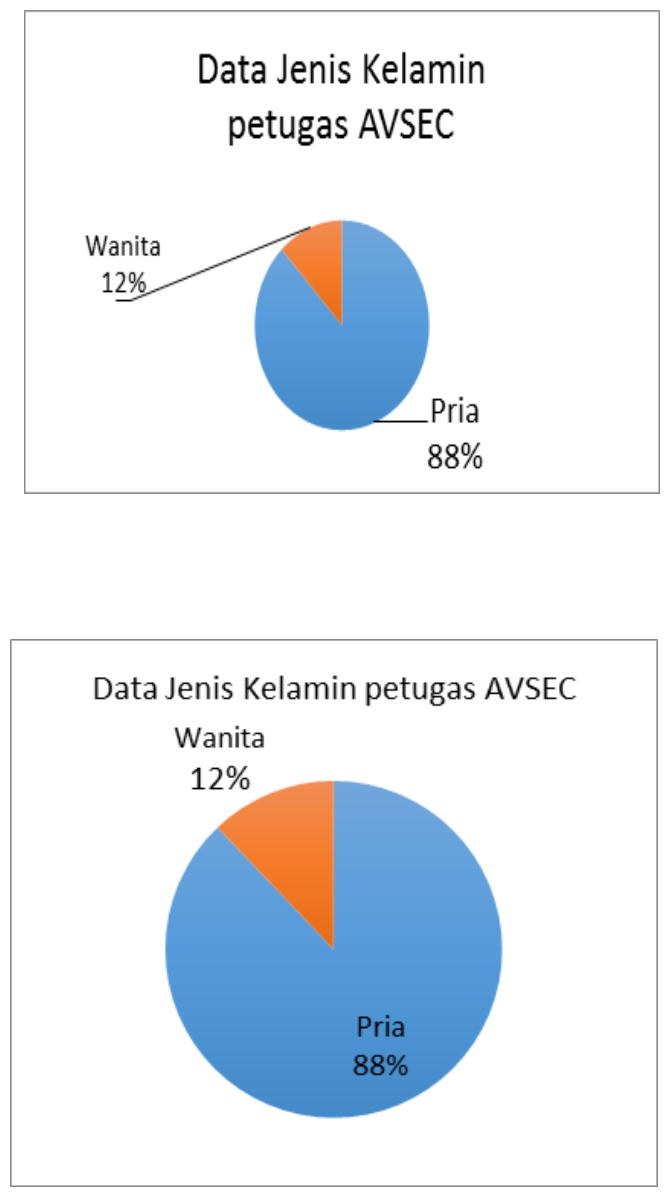

Data jumlah responden penumpang diambil dari yang angket yang dikembalikan oleh penumpang setelah kuesioner dibagikan ternyata jumlah responden pria dan wanita adalah sama, yang dapat diasumsikan mereka pada umumnya mempunyai selera yang sama ketika membutuhkan layanan penerbangan. Sedangkan untuk responden petugas AVSEC semuanya mengembalikan angket dan diperoleh data pria jumlahnya lebih banyak yaitu 58 orang 
dari pada wanita hanya 8 orang. Hal ini menunjukan bahwa sampai saat ini manajemen bandara masih menganggap jenis karakteristik pekerjaan lebih cocok bila dikerjakan oleh tenaga kerja pria. Namun dengan adanya variasi petugas wanita walaupun jumlahnya lebih kecil menunjukkan bahwa tidak semua karakteristik pekerjaan keamanan tepat apabila dikerjakan oleh pria misalnya pekerjaan pelayanan informasi, memeriksa penumpang wanita maupun petugas administrasi yang memerlukan ketekunan dan ketelitian yang prima.

\section{GAMBAR}

Usia Penumpang dan Petugas AVSEC
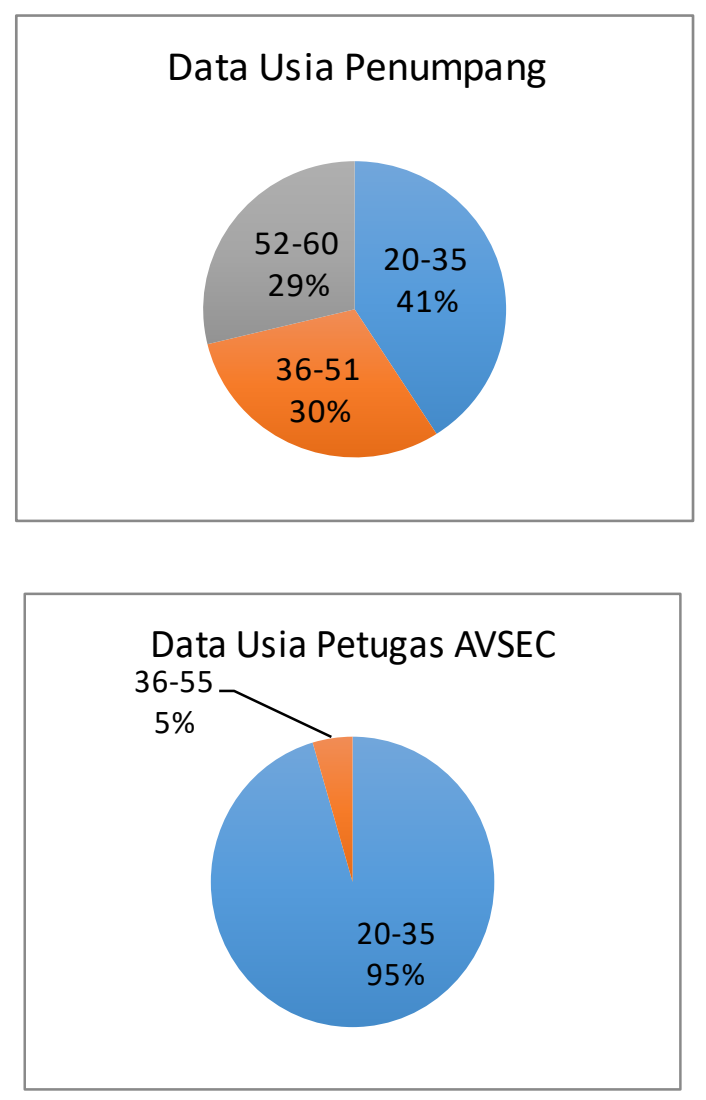

Responden usia penumpang diambil dari hasil penyebaran kuesioner yang dikembalikan selanjutnya dibagi dalam tiga kelompok usia dengan asumsi masing masing kelompok usia mempunyai selera yang berbeda yang akan berpengaruh pada interpretasinya terhadap layanan yang sama. Sedangkan petugas AVSEC semua angket yang dikembalikan tampak bahwa kelompok yang berusia 20-35 sangat dominan yaitu 95\%. Hal ini menunjukkan bahwa pihak manajemen Bandara menginginkan produktivitas kerjanya tinggi, cekatan dan terampil dalam menjalankan tugas pada kelompok usia tersebut.

\section{GAMBAR}

Tingkat pendidikan petugas AVSEC

Data pendidikan penumpang tidak

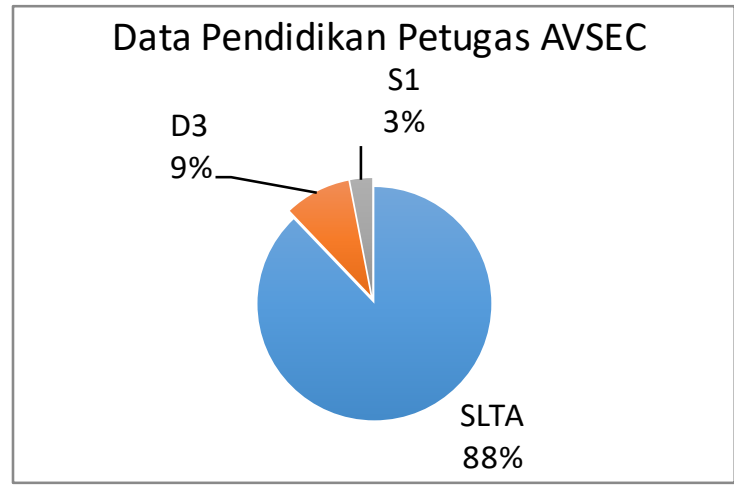

diambil dengan pertimbangan karena tidak diperlukan dalam penelitian. Sedangkan untuk petugas AVSEC datanya diakses karena menjadi salah satu karakteristk yang akan dianalisis secara tabel silang mengenai tingkat pemahaman dan ketrampilannya dalam menjalankan tugasnya sekaligus untuk membuktikan gambaran faktual dari hasil survey. Pada data petugas tampak bahwa lulusan SLTA mencapai $88 \%$,. Hal 
ini menggambarkan petugas lebih diarahkan untuk mengerjakan pekerjaan yang bersifat tehnis di lapangan dan berhadapan langsung dengan penumpang. Data dari mereka yang berasal dari S1 hanya 3\% karena jabatan pimpinan petugas AVSEC terbatas.

\section{ANALISIS DAN PEMBAHASAN}

\section{Aspek kemampuan.}

Berdasarkan Teori Robbin (2007:57) bahwa kemampuan terdiri dari dua kelompok yaitu kemampuan intelektual dan fisik. Dilihat dari aspek kemampuan, sebagian besar responden menyatakan mampu menjalankan Tupoksinya baik pria maupun wanita namun untuk kelompok pria lebih menonjol sedikit sebesar $2 \%$ ini berarti bahwa kelompok pria lebih mampu menjalankan untuk tugas tugas yang bebannya lebih berat atau yang berhubungan dengan fisik. Dalam kaitannya aspek kemampuan dengan usia terlihat bahwa petugas yang berusia 20-35 tahun lebih produktif dalam arti mempunyai stamina kuat, kecekatan, dan ketangkasan dalam menyelesaikan setiap pekerjaan dibandingkan petugas yang berusia 36 - 55 tahun. Perbedaan tersebut tampak dari data usia 2035 mencapai $40 \%$ sedangkan 36-55 hanya $36 \%$. Namun dalam hal ini bukan berarti kelompok 36-55 kurang cekatan, dengan bekal pengalaman yang memadai selama mereka bertugas maka tetap bisa menyelesaikan tugasnya dengan baik. Aspek pendidikan ternyata berbanding terbalik dengan kemampuan tehnis. Dari data yang terhimpun aspek penguasaan tugas lebih dominan dikuasai oleh petugas yang berasal dari lulusan D3 dibanding yang mayoritas petugas dari SLTA. Petugas dari S3 mencapai 64\% sedangkan SLTA hanya $45 \%$. Untuk petugas yang berasal dari S1 lebih rendah 5\% dari pada lulusan D3, hal ini menunjukkan bahwa pekerjaan sebagai petugas keamanan Bandara lebih tepat jika di pimpin oleh petugas dari D3 .

\section{GRAFIK}

Kemampuan Petugas dalam menjalankan TUPOKSI

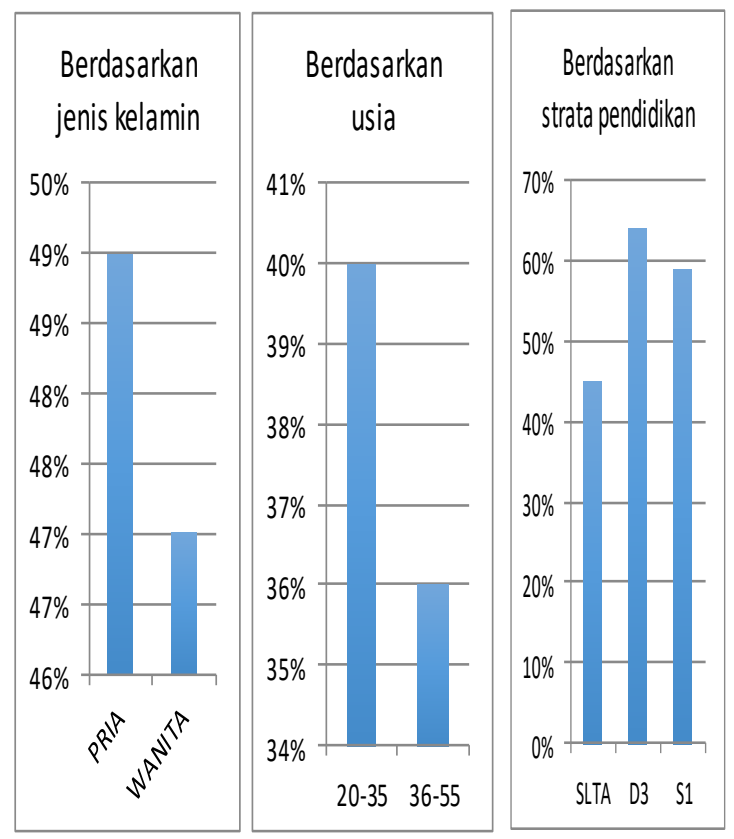

\section{Aspek Kepekaan. Menurut} Tondok $(2012,6) \quad$ Kepekaan sosial bukanlah suatu kemampuan yang dibawa anak sejak lahir, kepekaan sosial muncul dan berkembang dari dan melalui pengalaman 
yang hakekatnya merupakan hasil dari interaksi antara individu dengan lingkungannya. Dilihat dari aspek kepekaan maka petugas AVSEC yang memiliki jenis kelamin wanita lebih peka dibandingkan pria. Wanita memperoleh skor $60 \%$ sedangkan pria $52 \%$. Hal ini menunjukkan bahwa sesuai dengan naluri kewanitaan yang sensitif dan terbawa sejak lahir, lebih cocok untuk jenis pekerjaan yang memerlukan kepekaan tinggi misalnya penumpang yang dinilai dapat membahayakan keselamatan penerbangan. Apabila dilihat dari aspek pendidikan terlihat petugas yang berasal dari S1 lebih peka dibanding yang dari D3 ataupun SLTA, yaitu S1 memperoleh skor $73 \%$ jauh dibanding yang dari D3 dan SLTA masing masing sebesar 59\%. Data ini menunjukkan bahwa petugas berasal dari S1 pada umumnya lebih peka dalam menilai situasi keamanan Bandara sesuai dengan tanggung jawabnya dalam menduduki jabatan penting sebagai petugas keamanan.

\section{GRAFIK}

Kepekaan Petugas dalam melihat situasi di lapangan

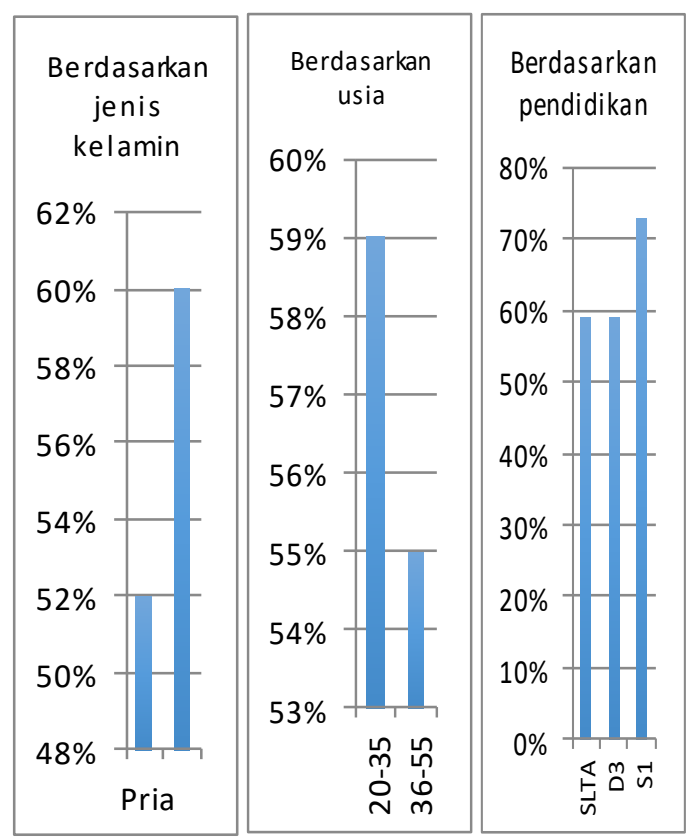

3. Aspek Kepuasan. Menurut Kuswadi (2006:17) kepuasan adalah perasaan senang atau kecewa seseorang yang muncul setelah membandingkan kinerja (hasil) produk yang dipikirkan terhadap kinerja (hasil) yang diharapkan. Dari hasil penelitian yang telah dilaksanakan, terlihat bahwa kepuasaan penumpang wanita terhadap kinerja petugas AVSEC masih jauh dari yang harapan, capaiannya sangat rendah dibawah $50 \%$. Faktor kewanitaan pada umumnya menuntut adanya pelayanan yang prima dan teliti hal ini kurang didapatkan dari layanan petugas AVSEC. Demikian pula jika ditinjau dari aspek usia ternyata kelompok usia 36-51 dan 52-60 hampir sama kurang puas dengan layanan dari petugas AVSEC. Ketidak puasan ini terjadi karena pada kelompok 
usia tersebut pada umumnya tingkat sosial mereka sudah tinggi, sehingga wajar apabila kelompok ini menuntut pelayanan yang lebih baik namun tidak diperoleh di bandara Halim Perdanakusuma.

\section{GRAFIK}

Tingkat kepuasan pengguna jasa transportasi udara
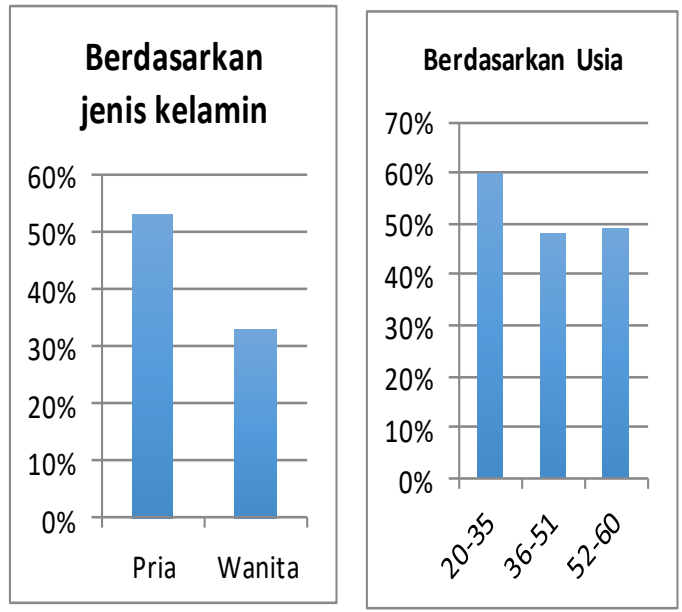

\section{KESIMPULAN}

Petugas AVSEC pada umumnya sudah memiliki kemampuan untuk menjalankan Tupoksinya dengan baik terutama pada petugas prianya pada kelompok usia antara 20-35 tahun. Hal ini sesuai dengan tugas pokoknya yang menuntut kepekaan terhadap situasi di lapangan yang menjadi tanggung jawabnya, namun sayangnya petugas paling peka justru hanya dimiliki oleh kelompok wanita yang jumlahnya sangat terbatas hanya 8 orang atau $12 \%$ dari 66 orang petugas keamanan Bandara. Kepekaan ini tentu berdampak pada kepuasan pengguna jasa transportasi penerbangan di Bandara Halim Perdanakusuma terutama pada kelompok wanita dan kelompok pria yang usia di atas 36 tahun.

\section{DAFTAR PUSTAKA}

Abdullah Fathoni. 2014, "Manajemen Kebandarudaraan Strategis", Koperasi BPA, Jakarta.

Adji, Adisasmita. 2014, "Tatanan Bandar Udara Nasional", Graha Ilmu, Yogyakarta

Anwar, Prabu Mangkunegara. 2011, "Manajemen Sumber Daya Manusia" PT. Remaja Rosdakarya, Jakarta.

Dwi Indah Mustiko Ningrum 2015 “Dampak Penggunaan facebook terhadap kepekaan sosial peserta didik di SMP Negri 1 Demak" Jurnal, Universitas Negri Semarang, Semarang.

Fandy Tjiptono dan Gregorius Chandra. 2006, Manajemen Kualitas Jasa, Yogyakarta.

Hadi Suharno. 2009, “Manajemen Perencanaan Bandar Udara", PT. Rajagrafindo Persada, Jakarta.

Kasmir. 2016, "Manajemen Sumber Daya Manusia (Teori dan Praktik), PT. Rajarafindo Persada, Jakarta.

Kotler Philip. 2007, Manajemen Pemasaran , jilid 2, PT Indeks, New Jersey.

Kuswadi. 2006, Cara Mengukur Kepuasan Karyawan. Jakarta : PT Elex Media Komputindo.

Lickona Thomas. 2008, "Pendidikan Karakter", Nusa Media, Bandung. Milwan Yudi. 2010, "Psikologi Pendidikan dan Aplikasinya", Gramedia, Jakarta. Priyatno Dwi. 2008, "Mandiri Belajar SPSS" Mediakom, Yogyakarta.

Raharjo, Sahid. 13 Mei 2015 ,Uji Validitas, Uji Asumsi Klasik, Uji Reliabilitas 


\section{JURNAL M-PROGRESS}

dan Uji Hipotesis diambil dari www.spssindonesia.com , 20 Mei 2016

Sarlito Wirawan. 2014, "Pengantar Psikologi Umum", PT. Rajagrafindo Persada, Jakarta.

Stephen Robin P. 2007, "Perilaku Organisasi”, PT. Indeks, Jakarta. Jurnal 